ADALAH : Buletin Hukum \& Keadilan

\title{
Coattail Effect Pada Ajang Pemilihan Umum Presiden 2019
}

\author{
Nur Rohim Yunus ${ }^{*}$
}

Komposisi perhelatan akbar pemilihan umum presiden 2019 dipastikan akan sama dengan pemilu presiden tahun 2014 yaitu pertarungan sengit antara Kubu Jokowi melawan kubu Prabowo. Bedanya kubu Jokowi hanya didukung lima partai, sedang kubu Prabowo didukung oleh enam partai. Kelima partai pendukung Jokowi itu adalah Partai Demokrasi Indonesia Perjuangan (PDIP), Nasional Demokrat (NASDEM), Partai Kebangkitan Bangsa (PKB), Partai Hati Nurani Rakyat (Hanura) dan Partai Keadilan dan Persatuan Indonesia (PKPI), atau lebih dikenal dengan sebutan Koalisi Indonesia Hebat (KIH). Sedang kubu Prabowo didukung enam partai politik yaitu Gerindra, Partai Keadilan Sejahtera (PKS), Partai Amanat Nasional (PAN), Partai Persatuan Pembangunan (PPP), Partai Bulan Bintang, dan Partai Golongan Karya (Golkar), atau dikenal dengan sebutan Koalisi Merah Putih (KMP). Sedang Partai Demokrat yang dinahkodai mantan Presiden SBY menjadi partai penyeimbang.

Perubahan koalisi yang terjadi di ajang perhelatan Pilpres 2019 terlihat dengan dukungan terhadap Jokowi lebih besar daripada Prabowo. Kubu Jokowi yang sekarang disebut dengan Koalisi Indonesia Kerja didukung oleh 9 Partai dengan penambahan dari partai Golkar dan PPP yang menyebrang dari Kubu Prabowo,

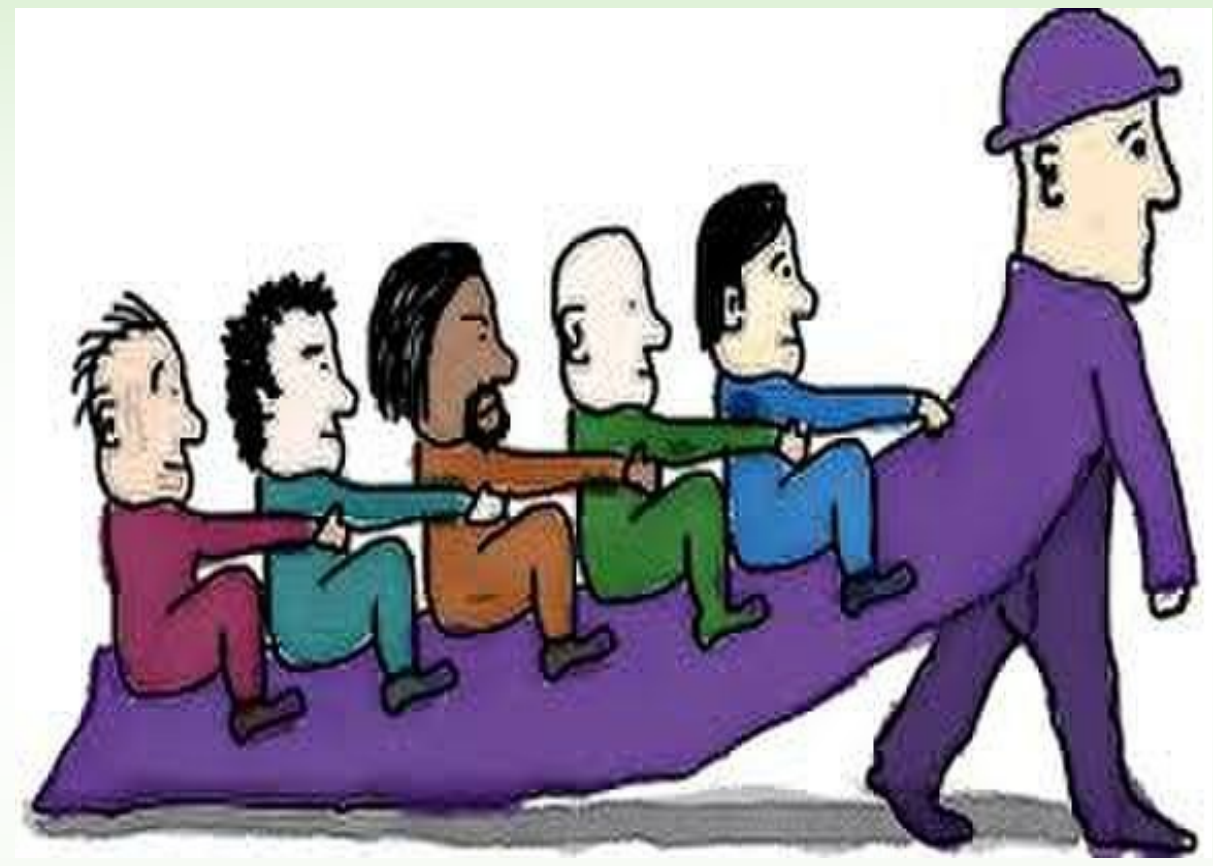

serta tambahan baru dari partai Perindo (Partai Persatuan Indonesia) dan Partai Solidaritas Indonesia (PSI), walaupun akhirnya Partai PKPI tidak lolos verifikasi KPU. Tentunya kubu Prabowo hanya mendapat dukungan minoritas 4 partai politik yaitu Gerindra, PAN, PKS dan tambahan baru partai Demokrat. Sedang Partai PBB tidak lolos verifikasi dan menyatakan netral.

Pemilihan Umum 2019 memang hanya dapat menelurkan dua pasangan saja, akibat pengaturan dalam pasal 222 Undang-Undang Nomor 7 Tahun 2017 yang berkaitan dengan presidential threshold 20\% yang didasarkan pada hasil pemilu DPR lima tahun sebelumnya.

Walaupun sebelumnya sempat diajukan uji materil ke Mahkamah Konstitusi (Rajab, 2017: 5). Perihal koalisi partai pengusung calon Presiden dan wakil Presiden diatur dalam norma Pasal 6A ayat (1), ayat (2), ayat (3) dan ayat (4) UUD NRI 1945. (Subhi, 2015: 343).

Itulah peta politik dari perseteruan dua kubu antara kubu Jokowi dan kubu Prabowo yang belum usai. Di perhelatan pilpres 2014 Jokowi memenangkan pilpres didampingi Jusuf Kalla yang memiliki basis massa yang besar, baik dari umat Islam sendiri maupun dari warga Indonesia timur, sedang Prabowo didampingi Hatta Rajasa juga tidak kalah kuat basis massanya. Pilpres 2019 Jokowi masih memanfaatkan ketokohan 
Islam calon wakil presiden dengan menunjuk Kiai Ma'ruf Amin sebagai calonnya. Sedang Prabowo memilih Sandiaga Uno pengusaha muda sebagai calon wakil presiden. Persaingan sengit siap digelar, dan dipastikan akan berdampak pada elektabiltas partai politik pengusung pada masing-masing kandidat. Dengan kata lain partai pengusung akan mendapat imbas suara akibat Coattail effect dukungan kepada calon yang dipilih oleh rakyat.

Coattail effect adalah istilah yang merujuk pada suatu tindakan yang menimbulkan pengaruh pada tindakan lain (pengaruh ikutan). Dalam terjemahan bebas diartikan sebagai efek kibasan buntut jas. Calon pemimpin yang diusung memiliki efek buntut jas terhadap elektabilitas suara pada partai pengusung nantinya. Karena pemilihan presiden bersamaan dengan pemilihan anggota legislatif, maka tentunya pilihan rakyat terhadap pasangan capres dan cawapres tidak jauh dari calon anggota dewan dari partai pengusungnya. Hal ini tentu berakibat pada sinergitas antara eksekutif terpilih dengan anggota dewan di parlemen nantinya (Haris, 2015: 22). Dengan demikian, akan tercipta koordinasi pemerintahan yang baik dan sinergis antara eksekutif dan legislatif karena kesamaan asal partai keduanya.

Efek ekor jas dapat dimaknai sebagai pengaruh figur dalam meningkatkan suara partai di pemilu. Figur tersebut berasal dari capres ataupun cawapres yang diusung.

Di Indonesia, efek ekor jas pernah mengalami kesuksesan besar. Misalnya, terjadi pada 2004 dan 2009 dengan figur Susilo Bambang Yudhoyono (SBY). Partai Demokrat yang baru berdiri 2001 tiba-tiba memperoleh suara signifikan pada Pemilu 2004. Bahkan pada 2009 menjadi pemenang pemilu. Rupanya, ketokohan SBY turut mempengaruhi tingkat perolehan Partai Demokrat di dua pemilu tersebut. Publik memilih Demokrat karena partai tersebut identik dengan figur SBY yang saat itu merupakan presiden dengan tingkat elektabilitas dan kepuasan publik yang tinggi. Hal sama terjadi pada Pemilu 2014, Partai PDIP menikmati efek ekor jas dari figur Joko Widodo (Jokowi). Bahkan, kini saat elektabilitas dan tingkat kepuasan publik terhadap Jokowi terus meningkat, tingkat keterpilihan PDIP pun semakin meroket dalam sejumlah hasil survei terakhir.

Kompetisi dalam perhelatan akbar pemilihan presiden 2019 tentunya tidak kalah seru, dan efek coattail pun sudah menjadi prediksi yang dipikirkan jauh-jauh hari oleh para partai pengusung. Dengan mendukung Jokowi atau Prabowo diharapkan partaipartai politik tersebut mendapat insentif elektoral. Minimal perolehan suara partai tidak menurun dibanding pemilu sebelumnya. Tidak heran jika di pinggir jalan tol atau perempatan jalan sering dijumpai baliho yang menunjukkan wajah ketua umum partai disandingkan dengan capres tertentu. Tak hanya itu, kerja politik mengais efek ekor jas juga terlihat ketika partai-partai pendukung capres berlomba-lomba menyorongkan cawapres. Dengan kadernya menjadi cawapres Jokowi atau Prabowo mereka berharap insentif elektoral mampu didapatkan secara maksimal.[]

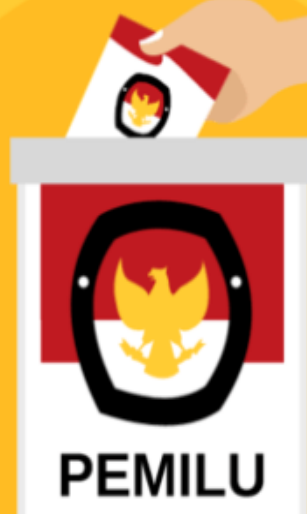

\section{Pustaka Acuan:}

* Penulis adalah Sekjen Pusat Studi Konstitusi dan Legislasi Nasional (Poskolegnas) UIN Jakarta.

Haris, Syamsuddin, dkk., Pemilu Nasional Serentak 2019, Jakarta: Electoral Research Institute - Lembaga Ilmu Pengetahuan Indonesia, 2015.

Rajab, Achmadudin. "Batas Pencalonan Presiden Dalam UU No. 7 Tahun 2017 Tentang Pemilihan Umum," dalam Jurnal RechtsVinding, Media Pembinaan Hukum Nasional, (2017)

Subhi, Ahmad Farhan, "Pengusulan Pasangan Calon Presiden dan Wakil Presiden Sebagai Peserta Pemilu Menurut Undang-Undang Pilpres", dalam Jurnal Cita Hukum, Vol. 3 No. 2 (2015).DOI: 10.15408/ jch.v2i2.2324.

'Adalah; Buletin Hukum dan Keadilan merupakan berkala ilmiah yang diterbitkan oleh Pusat Studi Konstitusi dan Legislasi Nasional (POSKO-LEGNAS), Fakultas Syariah dan Hukum UIN Syarif Hidayatullah Jakarta.

Penasehat: Prof. Dr. H. Abdul Ghani Abdullah, SH., Prof. Dr. H. A Salman Maggalatung, SH., MH. Pemimpin Redaktur: Indra Rahmatullah, Tim Redaktur: Nurrohim Yunus, Fathuddin, Mara Sutan Rambe, Muhammad Ishar Helmi, Erwin Hikmatiar. Penyunting: Latipah, Siti Nurhalimah. Setting \& Layout: Siti Romlah 